\title{
Marginal Zone B Cells in Neonatal Rats Express Intermediate Levels of CD90 (Thy-1)*
}

\author{
PETER M. DAMMERS ${ }^{\mathrm{a}}$, MONIQUE E. LODEWIJK ${ }^{\mathrm{b}}$, ANDRÉ ZANDVOORT $^{\mathrm{b}}$ and FRANS G.M. KROESE, ${ }^{\mathrm{a}}$ K $^{\dagger}$
}

\begin{abstract}
${ }^{a}$ Department of Cell Biology, Immunology Section, University of Groningen, A. Deusinglaan 1, NL-9713 AV Groningen, The Netherlands; ${ }^{\mathrm{b}}$ Department of Pathology and Laboratory Medicine, University Hospital Groningen, P.O. Box 30.001, NL-9700 RB Groningen, The Netherlands
\end{abstract}

\begin{abstract}
Here we show that marginal zone (MZ)-B cells in rats can already be detected in neonatal spleen from two days after birth. At this time point, morphologically distinct MZs are not present yet and the vast majority of B cells in spleen are located in a concentric area surrounding the T cell zones (PALS). Before MZs are obviously detectable in spleen (14 days after birth), MZ-B cells seem to be enriched at the outer zones of the concentric B cell areas. Similar to adult rats, neonatal MZ-B cells are intermediate-sized cells that express high levels of surface (s)IgM and HIS57 antigen, and low levels of sIgD and CD45R (HIS24). We show here, however, that in contrast to adult MZ-B cells, MZ-B cells (and also recirculating follicular (RF)-B cells) in neonatal rats express higher levels of CD90 (Thy-1). In adult rats, expression of CD90 on the B cell lineage is confined to immature B cells. We speculate that the expression of CD90 on neonatal MZ-B cells may have implications for their responsiveness to polysaccharide ( $\mathrm{T}$ cell-independent type 2 ) antigens.
\end{abstract}

Keywords: B cell; Marginal zone; Ontogeny; Spleen; Rat

\section{INTRODUCTION}

In mammals, splenic marginal zone (MZ)-B cells are functionally implicated in the antibody $(\mathrm{Ab})$ response against bloodborn micro-organisms, especially against encapsulated bacteria like Streptococcus pneumoniae, Neisseria meningitidis and Haemophilus influenzae (MacLennan and Liu, 1991; Spencer et al., 1998). The capsules of these bacteria consist of polysaccharides which characteristically elicit $\mathrm{T}$ cell-independent type 2 (TI-2) Ab responses upon infection (Mosier and Subbarao, 1982; Mond et al., 1995). Experiments in mice revealed that survival from infection with encapsulated bacteria strongly correlates with the ability of the host to mount a rapid anti-polysaccharide Ab response (Peltola et al., 1977; Feeney et al., 1996; Guo et al., 1997; Benedict and Kearney, 1999).

In humans, responsiveness to TI-2 antigens does not develop until several months after birth and does not reach adult levels until after 5 years of age (Pabst and Kreth, 1980; Rijkers et al., 1998). This might be one of the reasons that explains the high incidence of death resulting from infection with encapsulated bacteria in young children. A similar phenomenon is observed in mice, where responsiveness to TI-2 antigens also appears to develop relatively late in ontogeny (Mosier et al., 1977).
In addition to the immaturity of macrophages and the rather low serum levels of many components of the complement pathway (especially components of the alternative pathway) (Pabst and Kreth, 1980), the weak TI-2 antibody responses in neonates and young children may well result from the absence and/or immaturity of the splenic MZ-B cells at childhood (Timens et al., 1989; Rijkers et al., 1998; Zandvoort et al., 2001a). In both human and rodent spleen, B cell follicles and MZs have not yet developed at birth (Friedberg and Weissman, 1974; Dijkstra and Dopp, 1983; Kroese et al., 1987; Timens et al., 1989). Dijkstra and Dopp, 1983 showed by immunohistology using polyclonal Abs that MZ-B cells in rats can be phenotypically distinghuished in the spleen as early as 6 days after birth. At this time, B cells are found in spleen in a concentric ring surrounding the periarteriolar lymphoid shealth (PALS). B cells located at the outermost border of these concentric areas, exhibit a strong membrane staining for IgM. Dijkstra and Dopp, 1983 suggested that these $\operatorname{IgM}^{\text {high }}$ cells likely represent MZ-B cells.

Several studies have provided evidence that MZ-B cells have a mixed origin and may contain "naive" (nonmemory) B cells as well as memory B cells. In human adults, most MZ-B cells are memory B cells, as is concluded from the somatic mutations found in

*Presented at the Proceedings of the 4th Germinal Center Conference, June 2002, Groningen, The Netherlands.

${ }^{\dagger}$ Corresponding author. Tel.: + 31-050-3632534. Fax: + 31-050-3632512. E-mail: f.g.m.kroese@med.rug.nl 
the immunoglobulin $(\mathrm{Ig})$ heavy $(\mathrm{H})$ chain variable region $\left(\mathrm{V}_{\mathrm{H}}\right)$ genes of human MZ-B cells (Dunn-Walters et al., 1995; Tierens et al., 1999). In addition, most MZ-B cells in man express the memory B cell marker CD27 (Tangye et al., 1998). In adult mice and rats, however, most MZ-B cells express germline encoded Ig $\mathrm{V}_{\mathrm{H}}$ genes, indicating that the vast majority of MZ-B cells in the spleen of these species consist of non-memory B cells (Makowska et al., 1999; Dammers et al., 2000). Similarly, very few memory $\mathrm{B}$ cells are found in human spleens at birth, as is illustrated by the fact that only very few MZ-B cells express CD27 at that time (Zandvoort et al., 2001a). We, and others demonstrated that the non-memory MZ-B cells can arise directly from mature RF-B cells without the requirement for proliferation (MacLennan and Liu, 1991; Dammers et al., 1999). In addition, we recently showed that MZ-B cells in normal adult rats display a selected Ig repertoire (Dammers et al., 2000), which is most likely the result of positive selection constrains (Martin and Kearney, 2000). If the MZ-B cell selection constrains are different during ontogeny, this might well be a possible explanation for the lack of responsiveness to TI-2 antigens in early mammalian life, because it would lead to a different and perhaps for TI-2 antigens less adapted Ig repertoire.

To address issues related to the selection process of MZ$B$ cells, we first studied the neonatal development of MZ-B cells in rats, in terms of phenotype and immunohistological localization in vivo. Here, we show that MZ-B cells can already be detected by flow cytometry and immunohistology by two days after birth. Furthermore, for at least the first three weeks after birth, neonatal MZ-B cells were found to express intermediate levels of the "immature B cell marker" CD90.

\section{RESULTS}

\section{Flow Cytometry Analysis Reveals the presence of Splenic MZ-B Cells already Two Days after Birth}

In order to study MZ-B cell development in neonatal rats, spleen cell-suspensions were prepared from 2-, 10-, 14- and 21-days old animals and analyzed by three-color flow cytometry. MZ-B cells can be detected in adult spleen by virtue of their unique phenotype: MZ-B cells are $\operatorname{sIgM}^{\text {high }} \operatorname{sIgD}{ }^{\text {low }} C D 45 R^{\text {low }} C D 90^{\text {neg }}$ and express high levels of an antigen recognized by the newly developed mAb HIS57 (Dammers et al., 1999). In adult rat spleen, staining for IgM and IgD reveals the presence of two B cell subsets: $\operatorname{sIgM}{ }^{\text {low }} \operatorname{sg} D^{\text {high }}$ and $\operatorname{sIgM}^{\text {high }} \operatorname{sIgD}^{\text {low }}$ B cells, both of which can be further subdivided by virtue of CD90 expression levels. The $\operatorname{sIgM}^{\text {low }} \operatorname{sIgD}^{\text {high }} \mathrm{B}$ cell subset comprise early recirculating follicular (ERF)-B cells $\left(\mathrm{CD} 90^{\text {high }}\right)$ and recirculating follicular (RF)-B cells $\left(\mathrm{CD} 90^{\text {neg }}\right)$, whereas the $\operatorname{sIgM}^{\text {high }} \operatorname{sIgD}^{\text {low }} \mathrm{B}$ cell subset contains newly formed (NF)-B cells (CD90 ${ }^{\text {high }}$ ) and MZ-B cells $\left(\mathrm{CD} 90^{\text {neg }}\right)$ (Kroese et al., 1995). Figure 1 shows that $\mathrm{sIgM}^{\text {high }} \operatorname{sIgD}^{\text {low }} \mathrm{B}$ cells predominate in spleen during

\section{spleen}
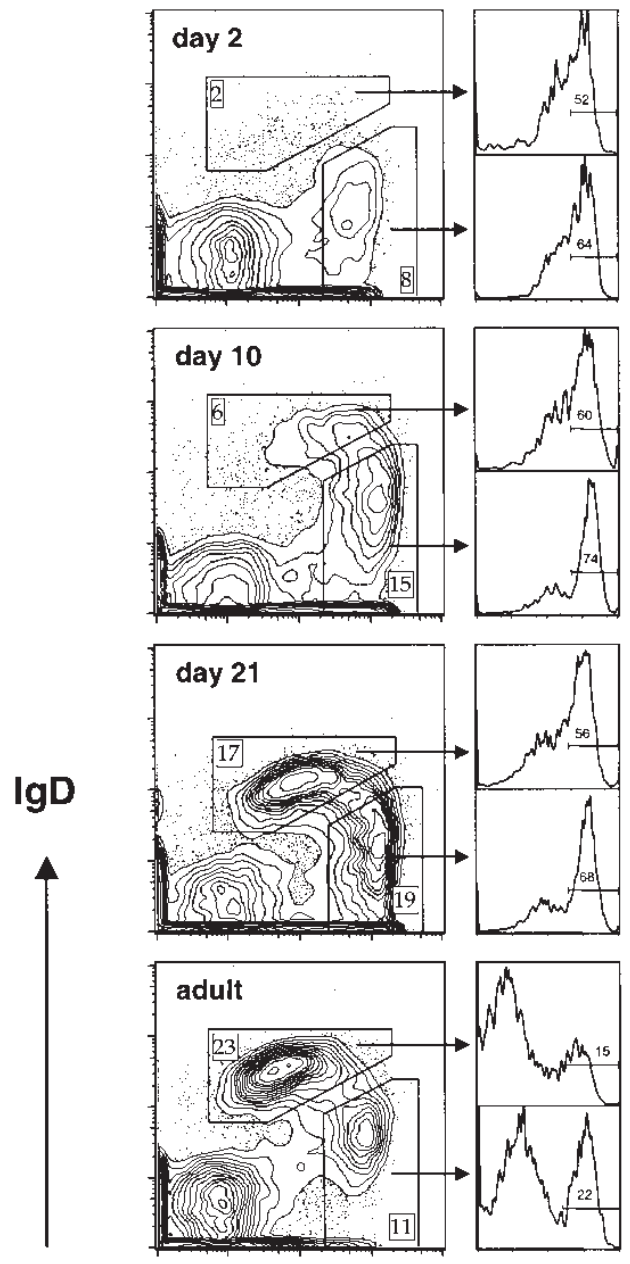

$\lg M$

CD90

FIGURE 1 Flow cytometry analysis of neonatal rat spleen stained for IgM, IgD and CD90. Spleens were taken 2, 10 and 21 days after birth and from adult rats (5-months-old). In adult rat spleen, the $\mathrm{sIgM}^{\text {high }} \mathrm{SIgD}^{\text {low }} \mathrm{B}$ cell subset consists of NF-B cells (CD90 ${ }^{\text {high }}$ ) and MZ-B cells $\left(C D 90^{\text {neg }}\right)$, and the $\operatorname{sIgM}^{\text {low }} \operatorname{sigD}{ }^{\text {high }} B$ cell subset consists of ERF-B cells (CD90 ${ }^{\text {high }}$ ) and RF-B cells $\left(C D 90^{\text {neg }}\right)$. Note the presence of cells that express intermediate levels of CD90 and the virtual absence of $\mathrm{CD} 90^{\text {neg }}$ cells within the $\operatorname{IgM} / \operatorname{IgD}$-defined $\mathrm{B}$ cell subsets during neonatal spleen development. Contour plots ( $5 \%$ probability) were generated on the basis of 40,000 events, after gating for lymphoid cells on the basis of forward-sideward scatter profiles. Numbers represent percentages within the lymphoid gate, except for CD90 where numbers represent percentage of cells within the respective $\operatorname{IgM} / \operatorname{IgD}$ gate.

the first three weeks after birth. Two days after birth, the percentage of $\operatorname{sIgM}^{\text {high }} \operatorname{sIgD}^{\text {low }} \mathrm{B}$ cells is about four times higher than the percentage of $\operatorname{sig} M^{\text {low }} \operatorname{sIgD}^{\text {high }} \mathrm{B}$ cells, whereas in adult rats there are generally about two times more $\operatorname{sIgM}^{\text {low }} \operatorname{sIgD}^{\text {high }} B$ cells than $\operatorname{sIgM}^{\text {high }} \operatorname{sIgD}^{\text {low }}$ $\mathrm{B}$ cells. Figure 1 also shows that, in contrast to adult animals, all IgM/IgD-defined neonatal B cells express intermediate or high levels of CD90, whereas CD $90^{\text {neg }}$ cells are virtually absent. Two days after birth, about 50\% 


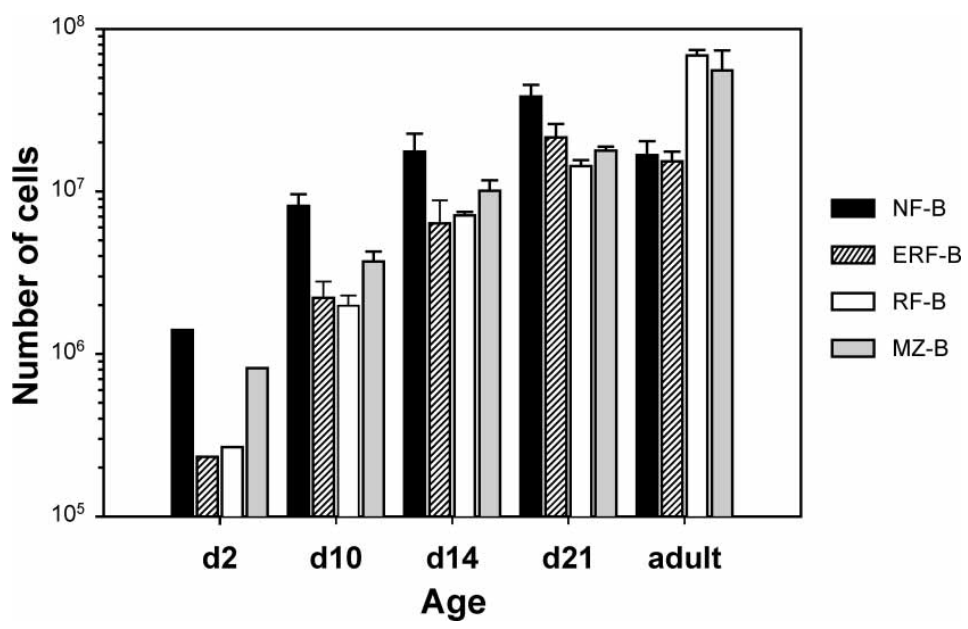

FIGURE 2 Absolute numbers of NF-B, ERF-B, RF-B and MZ-B cells in spleen of neonatal PVG rats (2, 10, 14 and 21 days after birth) and adult rats (5-months-old). B cell subsets were determined by means of three-color flow cytometry using anti-IgM, anti-IgD and anti-CD90 staining (see text). For neonatal animals, RF-B and MZ-B cells were defined as $\mathrm{CD} 90^{\text {int/neg }}$ cells (within the respective $\mathrm{IgM} / \mathrm{IgD}$ gate). For each time point, the absolute number of cells per subset is the average of three animals, except for the adult $(n=4)$. Error bars represent the standard deviation (SD).

of the splenic $\operatorname{sIgM}^{\text {high }}{ }_{\text {sIgD }}{ }^{\text {low }} B$ cells express high levels of CD90 and therefore represent NF-B cells (Fig. 1). As shown in Fig. 2, the absolute number of NF-B cells in neonatal spleen already reaches adult levels by 14 days after birth. At weaning (day 21), the number of NF-B cells in spleen exceeds that of adult rats by two-fold. The other $\mathrm{sIgM}^{\text {high }}{ }_{\mathrm{SIgD}}{ }^{\text {low }}$ neonatal $\mathrm{B}$ cells express intermediate levels of CD90, a phenotype that is not seen in adult animals. These neonatal $\mathrm{sIgM}^{\text {high }} \operatorname{sIgD}^{\text {low }} \mathrm{CD} 90^{\text {int }}$ cells are most probably MZ-B cells. MZ-B cells in adult rats express low levels of CD45R (HIS24) and high levels of HIS57 antigen. As we show in Fig. 3, cells with such a phenotype are also seen in neonatal spleens. Already two days after birth, low numbers of sIgM ${ }^{\text {high }}$ HIS5 $57^{\text {high }}$ and sIgM ${ }^{\text {high }} C D 45 R^{\text {low }}$ MZ-B cells can be distinguished. Consistent with a MZ-B cell phenotype, these cells are relatively large, as revealed by their higher forward-scatter profile, compared to other B cells in spleen. Furthermore, we show that neonatal MZ-B cells defined by staining for sIgM in combination with CD45R (HIS24) or HIS57 antigen, express intermediate levels of CD90. The CD90 expression levels are the highest on MZ-B cells taken from spleens two days after birth and these levels gradually diminish with age. Absolute numbers of MZ-B cells increase more than 10 -fold during the first three weeks of life (Fig. 2).

During the first three weeks after birth, the vast majority of the $\operatorname{sIgM}^{\text {low }} \operatorname{sIgD}^{\text {high }} \mathrm{B}$ cells express relatively high levels of CD90 and likely represent ERF-B cells (Fig. 1). In adult rats, ERF-B cells constitute only a relatively small proportion of $\operatorname{sgM}{ }^{\text {low }} \operatorname{sIgD}^{\text {high }} \mathrm{B}$ cells. The other B cells belonging to the $\operatorname{sIgM}^{\text {low }} \mathrm{sIgD}{ }^{\text {high }}$ subset, express intermediate levels of CD90. The expression levels of CD90 on these cells diminish gradually over time. We speculate here that the $\operatorname{IgM}^{\text {low }} \operatorname{SIgD}^{\text {high }} \mathrm{CD} 90^{\text {int }} \mathrm{B}$ cells may well represent RF-B cells that express some CD90, similar to MZ-B cells. Indeed, numbers of $\operatorname{sIgM}^{\text {low }} \operatorname{SIgD}^{\text {high }} \mathrm{CD} 90^{\text {int }}$
B cells increase with age (Fig. 2), which can be expected for the expanding RF-B cell pool.

Figure 4 shows that two days after birth, appreciable numbers of $\mathrm{sIgM}^{\text {neg }} \mathrm{CD} 90{ }^{\text {high }} \mathrm{CD} 24^{\text {high }}$ cells can be detected in rat spleen. In adult bone marrow these cells represent pro/pre-B cells (Hermans et al., 1997). This observation indicates that, in addition to bone marrow, B lymphopoiesis also takes place in the neonatal spleen. The pro/pre-B cells in spleen probably contribute to a rapid generation of NF-B cells only during the first week of life, because splenic pro/pre-B cells are virtually absent by 10 days of age.

\section{Immunohistochemical Staining Reveals the presence of MZ-B Cells in Neonatal Animals}

In order to study the in situ development of MZ and MZ-B cells in neonatal rat spleen, we stained serial frozen section of 2-, 10-, 14- and 21-days-old spleen for either IgM, IgD, Igк, TCR ${ }_{\alpha \beta}$, CD45R (HIS24), CD90 or HIS57 antigen. Two days after birth, small numbers of $\mathrm{TCR}_{\alpha \beta}^{+}$ $\mathrm{T}$ cells are found in spleen which are predominantly located in an area around the central arterioles (PALS). At this age, most $\operatorname{IgM}^{+} \mathrm{B}$ cells reside in a distinct concentric area surrounding the PALS (Fig. 5). B cells located at the outermost border of these concentric areas exhibit more (membranous) IgM staining compared to $\mathrm{B}$ cells of the inner part. In addition to B cells in these concentric areas, small numbers of $\operatorname{IgM}^{+} \mathrm{B}$ cells and $\mathrm{IgM}^{+}$plasma cells can also be detected scattered throughout the red pulp. Two days after birth, the vast majority of $\operatorname{IgM}^{+} \mathrm{B}$ cells in spleen seem to express Igк light-chains, since the number of $\operatorname{IgK}^{+}$and $\operatorname{IgM}^{+}$cells as well as the staining patterns for either IgM and Igk are very similar. Figure 5 shows that only a fraction of the $\mathrm{B}$ cells in the concentric areas surrounding the PALS express IgD. A similar fraction also stains for CD45R 





sIgMBM cells



$\operatorname{sigM}^{\text {neg }}$ spleen cells
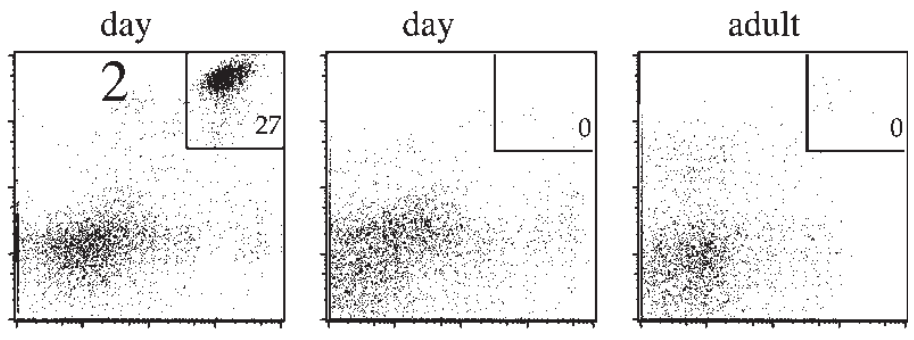

CD90

FIGURE 4 Flow cytometry analysis showing the presence of pro/pre-B cells in two-days-old rat spleen. Neonatal (day 2 and 10) and adult (5-monthsold) spleen cells as well as adult bone marrow cells were stained for IgM, CD90 and CD24. Shown is the CD90 vs. CD24 expression pattern for sIgM ${ }^{\text {neg }}$ cells. Dotplots were established on the basis of 40,000 events after gating for lymphoid cells using forward-sideward scatter profiles. Numbers represent percentages within the lymphoid gate. Note the presence of appreciable numbers of $\mathrm{CD} 90^{\text {high }} \mathrm{CD} 24^{\text {high }}$ cells (pro/pre-B cells) among the sIgM ${ }^{\text {neg }}$ spleen cells two days after birth.

(HIS24) (data not shown). $\mathrm{IgD}^{+}$and $\mathrm{CD}^{+} 5 \mathrm{R}^{+}$(HIS24) cells are enriched at the inner part of the concentric areas, and may well represent follicular type B cells (ERF-B and RF-B). Also in the red pulp some scattered CD45R ${ }^{+}$ (HIS24) cells are found (approximately in equal numbers as $\mathrm{IgM}^{+}$cells), whereas only limited numbers of $\mathrm{IgD}^{+}$ cells are present in this area. In addition to numerous cells in the red pulp, virtually all B cells in the concentric areas, stain for CD90. HIS57 staining was not observed in twodays-old spleen (data not shown).

While at day 10 after birth most B cells are still confined to the concentric areas surrounding the PALS, some initial

\section{$\lg M$}
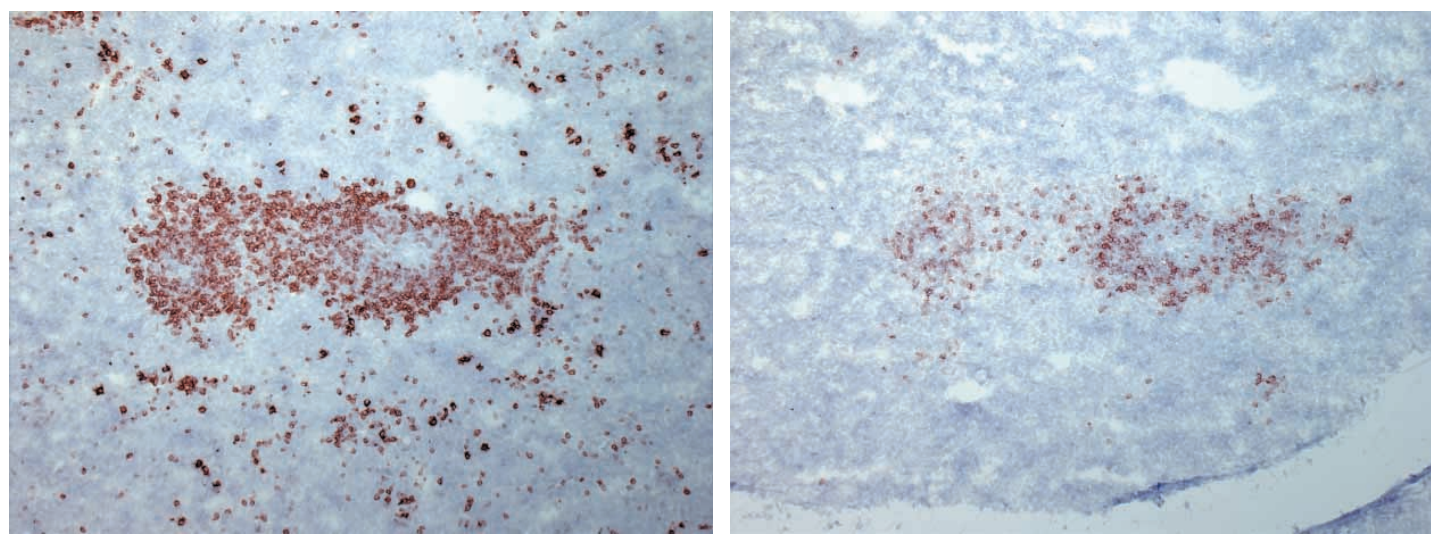

\section{day 2}

\section{day 10}


FIGURE 5 Indirect immunoperoxidase staining with anti-IgM (HIS40) and anti-IgD (MaRD3) of serial frozen sections of rat spleen 2 and 10 days after birth. At these time points, B cells are located in concentric areas surrounding the T cell areas (PALS); distinct B cell follicles and MZs are not present yet. Note that cells with the strongest membranous IgM staining are enriched at the outer zone of the concentric B cell areas, whereas IgD staining is confined to the inner parts. 
follicle development is seen and a marginal sinus can sometimes be distinguished (Fig. 5). At this age, follicular type $\mathrm{B}$ cells $\left(\mathrm{IgM}^{+}, \mathrm{IgD}^{+}\right.$and $\left.\mathrm{CD} 45 \mathrm{R}^{+}\right)$reside primarily in the inner parts of the concentric B cell areas. Cells in the outermost border of the concentric B cell areas display a strong membranous IgM and a weak HIS57 staining, but are $\mathrm{IgD}^{\text {low/neg }}$ and $\mathrm{CD} 45 \mathrm{R}^{\text {low/neg }}$ (Fig. 5; data for HIS57 and CD45R not shown). The phenotype of these cells is typical for MZ-B cells. Thus, although follicles and MZ are not yet clearly developed in 2-10-days-old spleens, their characteristic B cells appear to be present already and somehow spatially separated from each other.

From 14 days after birth, B cell follicles and MZ are clearly recognized in spleen. Two-color indirect immunofluorescent staining (Fig. 6) of 14-days-old spleen shows that most B cells located in the MZ express high levels of HIS57 antigen and only low levels of CD45R (HIS24), and thus represent typical MZ-B cells. On the other hand, most B cells present in follicles exhibit strong CD45R (HIS24) staining and are virtually negative for HIS57 antigen. Therefore, these cells represent typical follicular type of B cells. Although most follicular B cells in both neonatal and adult rat spleen are $\mathrm{CD} 45 \mathrm{R}^{\text {high }} \mathrm{HIS} 57^{\text {low/neg }}$, Fig. 6 shows that a minority of the follicular B cells stain negative or weakly for CD45R (HIS24) but strongly for HIS57 antigen. These $\mathrm{CD} 45 \mathrm{R}^{\text {low/neg }} \mathrm{HIS} 57^{\text {high }}$ follicular B cells are predominantly confined to the outer zone of the follicles. We also observed that $\mathrm{B}$ cells in this region of the follicles frequently stain strongly for IgM and weakly for IgD (data not shown). Therefore, these follicular B cells resemble phenotypically MZ-B cells. We currently do not know whether these cells are MZ-B cells, immediate MZ-B precursor cells or represent a novel (follicular) B cell subset.

\section{DISCUSSION}

Our study shows that already two days after birth, small numbers of MZ-B cells can be detected in rat spleen by flow cytometry. Similar to adult rats, these neonatal MZ-B cells are intermediate-sized $\operatorname{sIg} \mathrm{M}^{\text {high }} \mathrm{sIgD}{ }^{\text {low }}$ cells that express relatively low levels of CD45R (HIS24) and relatively high levels of HIS57 antigen. During the first 10 days after birth, however, immunohistologically defined MZ and follicles have not yet developed. In this period most splenic B cells reside in a distinct concentric area surrounding the PALS. Despite the lack of a morphologically distinct MZ, both $\mathrm{MZ}$ type and follicular type of $\mathrm{B}$ cells are present in neonatal spleen. MZ-B cells are enriched at the outermost border of the concentric areas, since cells located here exhibit strong membranous staining for $\operatorname{IgM}$ and are virtually negative for both $\mathrm{IgD}$ and CD45R (HIS24). Follicular B cells (ERF and RF B cells), on the other hand, are enriched at the inner part of the concentric areas, as the majority of cells at this location, stain for IgM, IgD and CD45R (HIS24). Our data therefore indicate that MZ-B cells appear earlier in ontogeny than initially described in the (immunohistological) study of Dijkstra and Dopp, 1983.
In neonatal spleen, NF-B cells are located in the red pulp, as many cells in this area stain for IgM and CD45R (HIS24), but not for $\operatorname{IgD}$. We cannot, however, rule out completely the possibility that (some) NF-B cells $\left(\operatorname{IgM}^{+} \operatorname{IgD}^{-} \mathrm{CD} 45 \mathrm{R}^{+}\right)$are also present in the concentric B cell areas.

Neonatal MZ-B cells display some subtle phenotypic differences with adult MZ-B cells. First, flow cytometry reveals that levels of HIS57 antigen on two-days-old MZ-B cells are about five times lower compared to adult rats. This lower expression level may explain the absence of HIS57 staining of spleen sections from two-days-old rats. Whether the lower HIS57 antigen expression levels have functional implications, awaits further characterization of the HIS57 antigen. Second, our study also shows that, in contrast to adult rats, neonatal MZ-B cells and RF-B cells express CD90 (Thy-1). CD90 is a heavily glycosylated, glycosyl phosphatidylinositol (GPI) anchored surface protein which is abundantly expressed on rodent thymocytes and mammalian neurons (Crawford and Barton, 1986; Firer et al., 1995; Killeen, 1997). In adult rats, CD90 is also expressed on the surface of immature B cells (pro/pre-B, NF-B, and ERF-B), but is almost completely absent from RF-B and MZ-B cells. (Crawford and Goldschneider, 1980; Kroese et al., 1995). Levels of CD90 on neonatal MZ-B cells diminish gradually with age; by three weeks after birth, these levels are still higher compared to adult MZ-B cells. The expression of this molecule on neonatal MZ-B cells may suggest that neonatal MZ-B cells are still immature. CD90 expression on neonatal RF-B and MZ-B cells is either due to active regulation of $\mathrm{CD} 90$ gene transcription or may reflect the fact that the vast majority of RF-B and MZ-B cells in neonatal animals are recently generated cells in which CD90 is not completely lost by turnover.

Timens et al., 1989 and Zandvoort et al., 2001a suggested that the lack of responsiveness to TI-2 antigens in early childhood (Pabst and Kreth, 1980; Rijkers et al., 1998) is probably due to the immaturity of the splenic MZ-B cells in first two years of human life. This conclusion was based on their observation that splenic MZ-B cells of newborns lack, or weakly express, CD21 (CR2). We like to speculate here that the expression of CD90 on neonatal rat MZ-B cells might also have implications for their ability to respond to TI-2 antigens. Experiments with CD90-deficient (Thy-1 ${ }^{-/-}$) mice have demonstrated that CD90 negatively regulates (inhibits) TCR-mediated signaling in thymocytes (Hueber et al., 1997). A similar inhibitory function of CD90 is also observed in neurons, where ligation of surface CD90 suppresses the outgrowth of neurites (Tiveron et al., 1992). Thus, CD90 could also play an inhibitory role in $\mathrm{B}$ cell receptor (BCR) signaling and therefore negatively affect $\mathrm{B}$ cell responsiveness to TI-2 antigens.

In mice, MZ-B and B-1 cells share several phenotypic and functional characteristics, but differ, however, with respect to their developmental origin and anatomical location (Martin and Kearney, 2001). In contrast to splenic MZ-B cells, B-1 cells are self-replenishing and are 


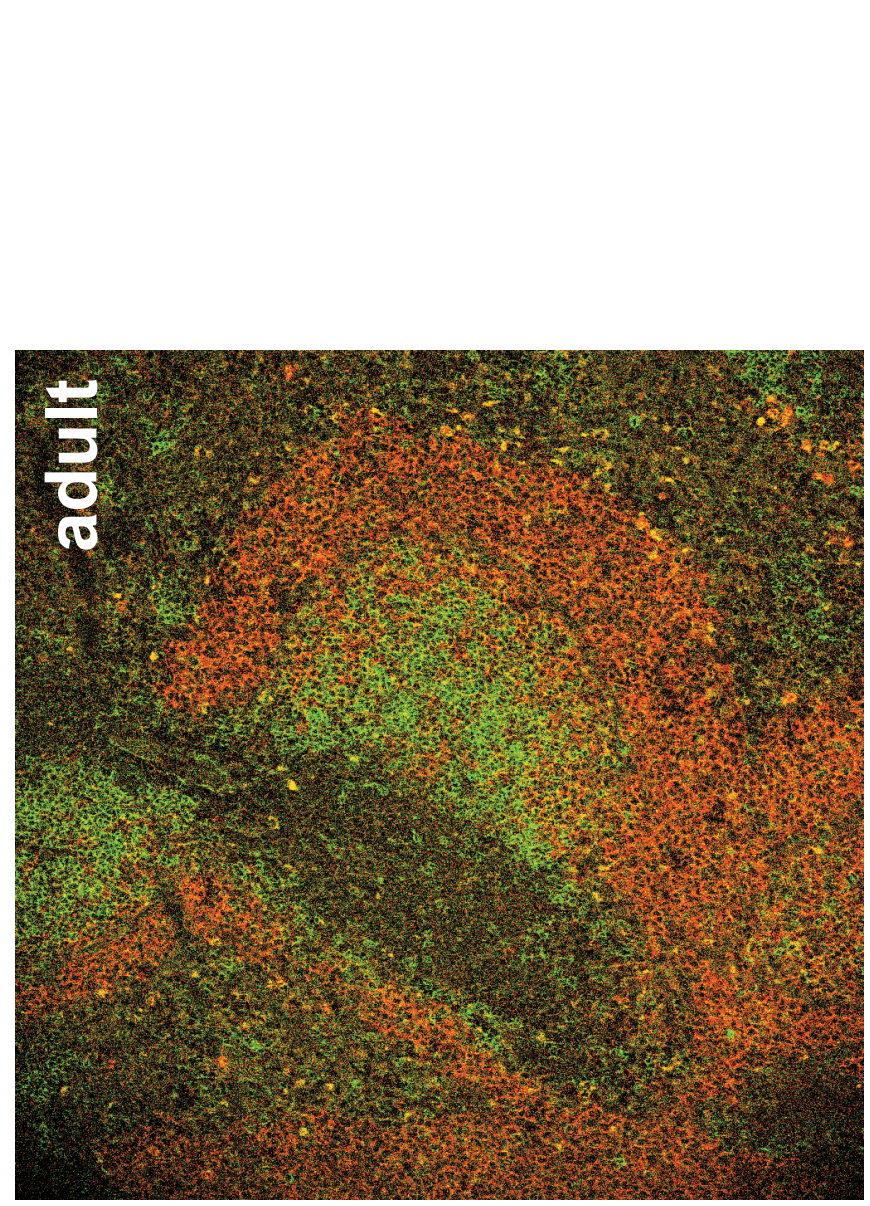

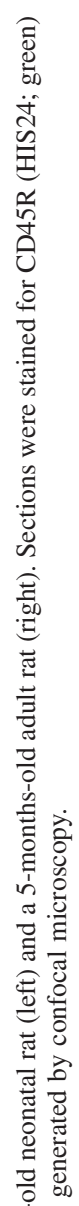

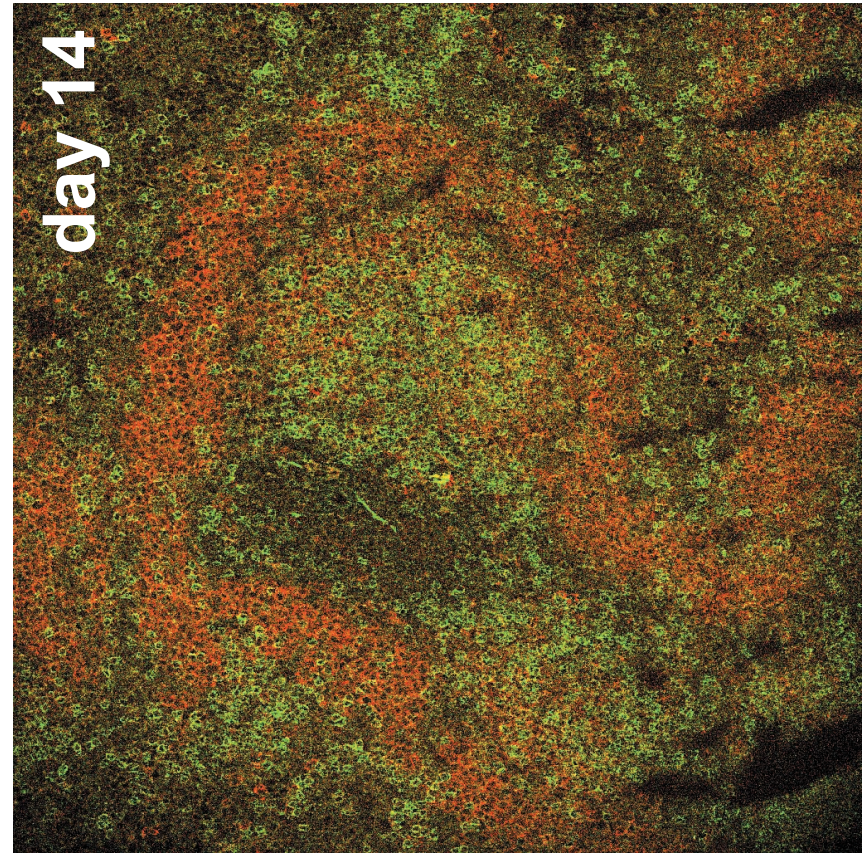

究苛

t

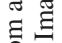

它

플

要

要量

ถิ ปี

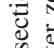

동ำ

诃

on

灵

章

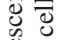



言行

造

을

훙

告要

窝佥 
enriched in coelomic (peritoneal and pleural) cavities. There are no indications that MZ-B cells can become B-1 cells and vice versa. So far, we have not unequivocally detected the homologue of murine B-1 cells in the rat (Vermeer et al., 1994). However, in a previous study, we observed a novel, previously unidentified B cell subset in the peritoneal cavity of SCID mice, reconstituted with rat fetal liver cells (rat $\rightarrow$ SCID mouse chimeras) (Deenen et al., 1997). Flow cytometry analysis of these peritoneal rat-derived cells revealed the following phenotype: $\operatorname{sIgM}^{\text {high }} \mathrm{CD} 45 \mathrm{R}^{\text {low }} \mathrm{HIS} 57^{\text {high }}$ CD90 ${ }^{\text {int }}$. We speculated that these cells might represent the rat homologue of murine B-1 cells. This study shows that neonatal MZ-B cells have the same phenotype. We consider it, however, as unlikely that the sIgM ${ }^{\text {high }} \mathrm{CD} 45 \mathrm{R}^{\text {low }} \mathrm{HIS} 57^{\text {high }} \mathrm{CD} 90^{\text {int }} \mathrm{B}$ cells in neonatal rat spleen are in fact, B-1 cells, because (i) CD90 expression levels on neonatal $\operatorname{sIgM}^{\text {high }} \mathrm{CD} 45 \mathrm{R}^{\text {low }}$ HIS57 $7^{\text {high }} \mathrm{B}$ cells gradually diminish with age and (ii) besides the $\mathrm{SIgM}{ }^{\text {high }} \mathrm{CD} 45 \mathrm{R}^{\text {low }} \mathrm{HIS} 57^{\text {high }} \mathrm{CD} 90^{\text {int }}$ cells, there are no substantial numbers of $\operatorname{sIg} M^{\text {high }} C D 45 R^{\text {low }}$ HIS5 $7^{\text {high }} \mathrm{CD} 90^{\text {neg }}$ cells (i.e. the phenotype of adult MZ-B cells), even not at time points that MZs are well developed. Whether the peritoneal $\operatorname{sIgM}^{\text {high }} \mathrm{CD} 45 \mathrm{R}^{\text {low }}$ HIS5 $7^{\text {high }} \mathrm{CD} 90^{\text {int }} \mathrm{B}$ cells in rat $\rightarrow$ SCID mouse chimeras are indeed the rat homologue of murine B-1 cells still remains to be resolved.

\section{MATERIALS AND METHODS}

\section{Animals and Flow Cytometry}

Pregnant female and adult male PVG rats (PVG/OlaHsd) were obtained from Harlan Netherlands, Horst, The Netherlands. Male rats were obtained at 10 weeks of age and killed at 5-months of age. Rats were housed at the Central Animal Facility of the Faculty of Medical Sciences (University of Groningen, Groningen, The Netherlands) and reared under pathogen free (SPF) conditions. Spleen and bone marrow cell-suspensions were prepared as described before (Dammers et al., 1999). Cells were stained for flow cytometry by a combination of the following FITCconjugated, PE-conjugated or biotinylated mouse anti-rat mAbs: HIS40 (anti-IgM) (Kroese et al., 1990), MaRD3 (anti-IgD; kind gift from Dr. H. Bazin, University of Louvain, Brussels, Belgium), HIS57 (Pharmingen, San Diego, CA) (Dammers et al., 1999), OX-7 or HIS51 (CD90; Pharmingen), HIS24 (CD45R (B220); Pharmingen), and HIS50 (CD24, heat-stable antigen) (Hermans et al., 1997). Biotinylated $\mathrm{mAbs}$ were revealed by streptavidinallophycocyanin or streptavidin-Cy-Chrome (Pharmingen). FlowJo software (version 3.6; Tree Star, San Carlos, CA) was used for flow cytometry data analysis.

\section{Immunohistology of Splenic Tissue Sections}

Splenic tissue was snap frozen in isopentane at $-80^{\circ} \mathrm{C}$ and stored at $-80^{\circ} \mathrm{C}$. Indirect immunoperoxidase labeling of spleen sections was performed according to Zandvoort et al., 2001b. The following mAbs were used for indirect immunoperoxidase labeling: HIS8 (Igк), HIS24 (CD45R), HIS40 (IgM) (Kroese et al., 1990), HIS57 (Dammers et al., 1999), MaRD3 (IgD; kind gift from Dr. H. Bazin, University of Louvain, Brussels, Belgium), ER-04 (CD90) (Vaessen et al., 1985), and R73 (TCR $\alpha \beta$ ) (Hünig et al., 1989). For indirect immunofluorescent labeling of spleen sections, cryostat sections of $5 \mu \mathrm{m}$ were used. Sections were air-dried and fixed in acetone $\left(-20^{\circ} \mathrm{C}\right)$ for $10 \mathrm{~min}$. Slides were incubated for $1 \mathrm{~h}$ in phosphate buffered saline (PBS) containing appropriately diluted HIS24 (IgG2b) and HIS57 (IgG1) mAbs. After rinsing for $3 \times 5$ min with PBS, the slides were incubated for $30 \mathrm{~min}$ in PBS containing 3\% (v/v) normal rat serum and appropriately diluted goat anti-mouse IgG2b (FITC) and goat antimouse IgG1 (TRITC) polyclonal antiserum (Southern Biotechnology Associates, Birmingham, AL). After rinsing for $3 \times 5$ min with PBS, sections were counterstained using $4^{\prime}$, 6-diamidino-2-phenylindole, dihydrochloride (DAPI; Molecular Probes, Eugene, OR) according to the manufacturers recommendations, and subsequently embedded in Vectashield H-1000 mounting medium (Vector Laboratories, Burlingame, CA). Immunofluorescent staining was revealed on a Leica TCS SP2 Confocal Microscope using Leica imaging software (version 2.0; Leica Microsystems, Wetzlar, Germany).

\section{Acknowledgements}

Authors thank Geert Mesander for flow cytometry assistance and Dick Huizinga for DTP.

\section{References}

Benedict, C.L. and Kearney, J.F. (1999) "Increased junctional diversity in fetal B cells results in a loss of protective anti-phosphorylcholine antibodies in adult mice", Immunity. 10, 607-617.

Crawford, J.M. and Goldschneider, I. (1980) "Thy1 antigen and B lymphocyte differentiation in the rat", J. Immunol. 124, 969-976.

Crawford, J.M. and Barton, R.W. (1986) "Thy-1 glycoprotein: structure, distribution, and ontogeny", Lab. Investig. 54, 122-135.

Dammers, P.M., de Boer, N.K., Deenen, G.J., Nieuwenhuis, P. and Kroese, F.G.M. (1999) "The origin of marginal zone B cells in the rat", Eur. J. Immunol. 29, 1522-1531.

Dammers, P.M., Visser, A., Popa, E.R., Nieuwenhuis, P. and Kroese, F.G.M. (2000) "Most marginal zone B cells in rat express germline encoded $\mathrm{Ig} \mathrm{V}_{\mathrm{H}}$ genes and are ligand selected", J. Immunol. 165, 6156-6169.

Deenen, G.J., Dammers, P.M., de Boer, T. and Kroese, F.G.M. (1997) "Identification of a novel rat B cell subset in the peritoneal cavity of xenogeneic rat to mouse SCID chimeras", Transplant. Proc. 29, $1752-1753$.

Dijkstra, C.D. and Dopp, E.A. (1983) "Ontogenetic development of T- and B-lymphocytes and non-lymphoid cells in the white pulp of the rat spleen", Cell Tissue Res. 229, 351-363.

Dunn-Walters, D.K., Isaacson, P.G. and Spencer, J. (1995) "Analysis of mutations in immunoglobulin heavy chain variable region genes of microdissected marginal zone (MGZ) B cells suggests that the MGZ of human spleen is a reservoir of memory B cells", J. Exp. Med. 182, 559-566.

Feeney, A.J., Atkinson, M.J., Cowan, M.J., Escuro, G. and Lugo, G. (1996) "A defective $\mathrm{V}_{\text {kappa }} \mathrm{A} 2$ allele in Navajos which may play a role 
in increased susceptibility to Haemophilus influenzae type b disease", J. Clin. Investig. 97, 2277-2282.

Firer, M.A., Zacharia, B.Z., Kostikov, M. and Irlin, Y. (1995) "The Thy-1 molecule: its properties and functions", Isr. J. Med. Sci. 31, 382-386.

Friedberg, S.H. and Weissman, I.L. (1974) "Lymphoid tissue architecture. II. Ontogeny of peripheral T and B cells in mice: evidence against Peyer's patches as the site of generation of B cells", J. Immunol. 113, 1477-1492.

Guo, W.X., Burger, A.M., Fischer, R.T., Sieckmann, D.G., Longo, D.L. and Kenny, J.J. (1997) "Sequence changes at the V-D junction of the $\mathrm{V}_{\mathrm{H}} 1$ heavy chain of anti-phosphocholine antibodies alter binding to and protection against Streptococcus pneumoniae", Int. Immunol. 9, 665-677.

Hermans, M.H., Deenen, G.J., de Boer, N., Bo, W., Kroese, F.G.M. and Opstelten, D. (1997) "Expression of HIS50 Ag: a rat homologue of mouse heat-stable antigen and human CD24 on B lymphoid cells in the rat", Immunology 90, 14-22.

Hueber, A.O., Bernard, A.M., Battari, C.L., Marguet, D., Massol, P., Foa, C., Brun, N., Garcia, S., Stewart, C., Pierres, M. and He, H.T. (1997) "Thymocytes in Thy- $1^{-1-}$ mice show augmented TCR signaling and impaired differentiation", Curr. Biol. 7, 705-708.

Hünig, T., Wallny, H.-J., Hartley, J.K., Lawetzky, A. and Tiefenthaler, G. (1989) "A monoclonal antibody to a constant determinant of the rat $\mathrm{T}$ cell antigen receptor that induces $\mathrm{T}$ cell activation. Differential reactivity with subsets of immature and mature T lymphocytes", J. Exp. Med. 169, 73-86.

Killeen, N. (1997) "T-cell regulation: Thy-1-hiding in full view", Curr. Biol. 7, R774-R777.

Kroese, F.G.M., Wubbena, A.S., Kuijpers, K.C. and Nieuwenhuis, P. (1987) "The ontogeny of germinal centre forming capacity of neonatal rat spleen", Immunology 60, 597-602.

Kroese, F.G.M., Butcher, E.C., Lalor, P.A., Stall, A.M. and Herzenberg, L.A. (1990) "The rat B cell system: the anatomical localization of flow cytometry-defined B cell subpopulations", Eur. J. Immunol. 20, $1527-1534$.

Kroese, F.G.M., de Boer, N.K., de Boer, T., Nieuwenhuis, P., Kantor, A.B. and Deenen, G.J. (1995) "Identification and kinetics of two recently bone marrow-derived $\mathrm{B}$ cell populations in peripheral lymphoid tissues", Cell. Immunol. 162, 185-193.

MacLennan, I.C.M. and Liu, Y.-J. (1991) "Marginal zone B cells respond to both polysaccharide antigens and protein antigens", Res. Immunol. 142, 346-351.

Makowska, A., Faizunnessa, N.N., Anderson, P., Midtvedt, T. and Cardell, S. (1999) "CD1 ${ }^{\text {high }}$ B cells: a population of mixed origin", Eur. J. Immunol. 29, 3285-3295.

Martin, F. and Kearney, J.F. (2000) "Positive selection from newly formed to marginal zone B cells depends on the rate of clonal production, CD19, and Btk", Immunity 12, 39-49.

Martin, F. and Kearney, J.F. (2001) "B1 cells: similarities and differences with other B cell subsets", Curr. Opin. Immunol. 13, 195-201.
Mond, J.J., Lees, A. and Snapper, C.M. (1995) "T cell-independent antigens type 2", Аппи. Rev. Imтипоl. 13, 655-692.

Mosier, D.E. and Subbarao, B. (1982) "Thymus-independent antigens: complexity of B-lymphocyte activation revealed", Immunol. Today $\mathbf{3}$, 217-222.

Mosier, D.E., Mond, J.J. and Goldings, E.A. (1977) "The ontogeny of thymic independent antibody responses in vitro in normal mice and mice with an X-linked B cell defect", J. Immunol. 119, 1874-1878.

Pabst, H.F. and Kreth, H.W. (1980) "Ontogeny of the immune response as a basis of childhood disease", J. Pediatr. 97, 519-534.

Peltola, H., Kayhty, H., Sivonen, A. and Makela, H. (1977) "Haemophilus influenzae type b capsular polysaccharide vaccine in children: a double-blind field study of 100,000 vaccinees 3 months to 5 years of age in Finland", Pediatrics 60, 730-737.

Rijkers, G.T., Sanders, E.A.M., Breukels, M.A. and Zegers, B.J.M. (1998) "Infant B cell responses to polysaccharide determinants", Vaccine 16, 1396-1400.

Spencer, J., Perry, M.E. and Dunn-Walters, D.K. (1998) "Human marginal-zone B cells", Immunol. Today 19, 421-426.

Tangye, S.G., Liu, Y.-J., Aversa, G., Phillips, J.H. and de Vries, J.E. (1998) "Identification of functional human splenic memory B cells by expression of CD148 and CD27", J. Exp. Med. 188, $1691-1703$.

Tierens, A., Delabie, J., Michiels, L., Vandenberghe, P. and de WolfPeters, C. (1999) "Marginal-zone B cells in the human lymph node and spleen show somatic hypermutations and display clonal expansion", Blood 93, 226-234.

Timens, W., Boes, A., Rozeboom-Uiterwijk, T. and Poppema, S. (1989) "Immaturity of the human splenic marginal zone in infancy. Possible contribution to the deficient infant immune response", J. Immunol. 143, 3200-3206.

Tiveron, M.C., Barboni, E., Pliego Rivero, F.B., Gormley, A.M., Seeley, P.J., Grosveld, F. and Morris, R. (1992) "Selective inhibition of neurite outgrowth on mature astrocytes by Thy-1 glycoprotein", Nature 355, 745-748.

Vaessen, L.M., Joling, P., Tielen, F.J. and Rozing, J. (1985) "New surface antigens on cells in the early phase of T-cell differentiation, detected by monoclonal antibodies", Adv. Exp. Med. Biol. 186, 251-260.

Vermeer, L.A., de Boer, N.K., Bucci, C., Bos, N.A., Kroese, F.G.M. and Alberti, S. (1994) "MRC OX19 recognizes the rat CD5 surface glycoprotein, but does not provide evidence for a population of CD5 ${ }^{\text {bright }}$ B cells", Eur. J. Immunol. 24, 585-592.

Zandvoort, A., Lodewijk, M.E., de Boer, N.K., Dammers, P.M., Kroese, F.G.M. and Timens, W. (2001a) "CD27 expression in the human splenic marginal zone: the infant marginal zone is populated by naive B cells", Tissue Antigens 58, 234-242.

Zandvoort, A., Lodewijk, M.E., Klok, P.A., Dammers, P.M., Kroese, F.G.M. and Timens, W. (2001b) "Slow recovery of follicular B cells and marginal zone B cells after chemotherapy: implications for humoral immunity", Clin. Exp. Immunol. 124, 172-179. 


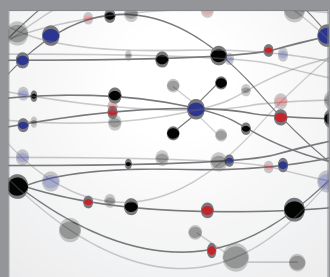

The Scientific World Journal
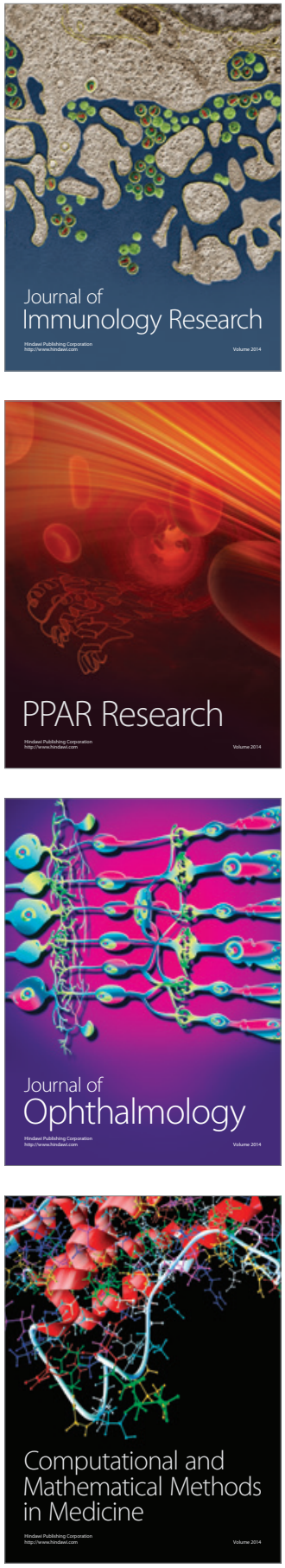

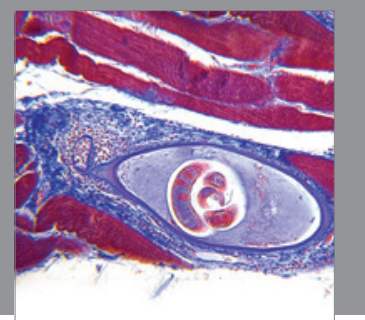

Gastroenterology

Research and Practice
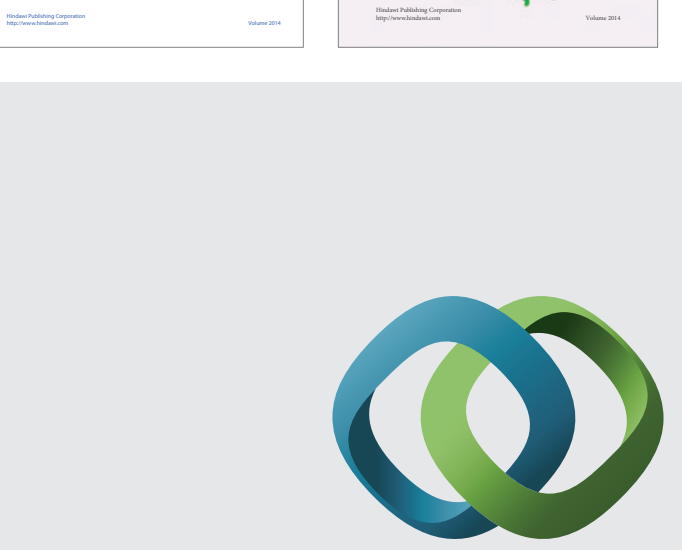

\section{Hindawi}

Submit your manuscripts at

http://www.hindawi.com
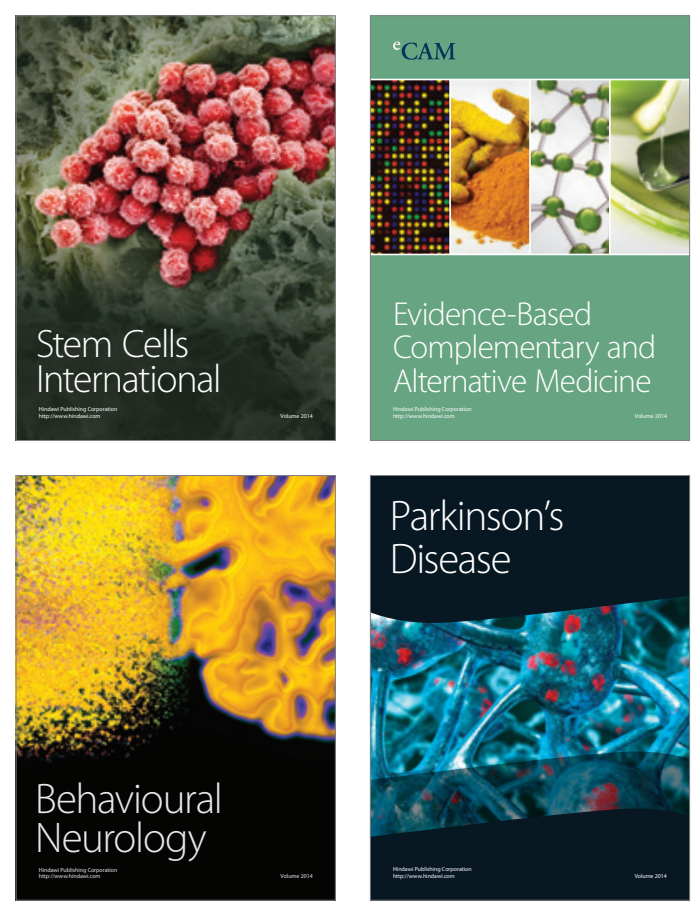

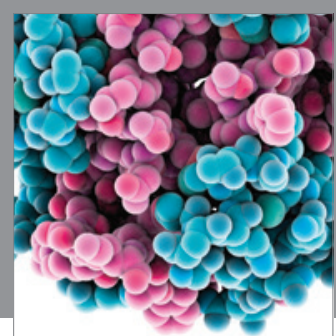

Journal of
Diabetes Research

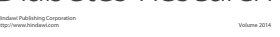



Disease Markers
